\title{
Yutma Güçlüğü ile Başlayan Atipik Miller-Fisher Sendromu Olgusu
}

\author{
Atypical Miller-Fisher Syndrome Case Which is Start with Swallowing Difficulties \\ Recep YEVGi' ${ }^{1}$, Recep DEMIR ${ }^{1}$, Musa GÜMÜŞDERE ${ }^{2}$, Gökhan ÖZDEMIR ${ }^{1}$, Hızır ULVi ${ }^{1}$ \\ ${ }^{1}$ Atatürk Üniversitesi Tıp Fakültesi, Nöroloji AD, Erzurum \\ ${ }^{2}$ Atatürk Üniversitesi Tıp Fakültesi, Biyokimya AD, Erzurum
}

\begin{abstract}
ÖZET
Ataksi, arefleksi ve oftalmopleji ile karakterize Miller-Fisher sendromu (MFS), ilk kez 1956 yılında farklı bir klinik antite olarak tanımlandı. MFS, Guillain-Barre Sendromu (GBS)'nun bir varyantı olarak kabul edilir ve GBS olgularının \%5-10'nunu oluşturur. Hastalığın klinik seyrinde ataksi, oftalmopleji, arefleksi, pitoz, diplopi, midriyazis, fasial paralizi, hipoestezi ve nadiren kuadriparezi görülebilir. MFS klinik bir tanı olmasına rağmen etkilenen birçok hastada Anti-GQ1b antikorunun pozitif olmasıyla da serolojik olarak doğrulanabilir. Biz bu makalede yutma güçlüğü ile gelen atipik bir MFS olgusu sunduk.
\end{abstract}

Anahtar Kelimeler: Ataksi; arefleksi; oftalmopleji; yutma.

\begin{abstract}
Miller-Fisher syndrome (MFS); characterized by ataxia, areflexia, and ophthalmoplegia, was first recognized as a distinct clinical entity in 1956. MFS is considered a variant of Guillain-Barre syndrom(GBS), accounting for 5 to $10 \%$ of GBS cases. Ataxia, ophthalmoplegia, areflexia, ptosis, diplopia, mydriasis, facial paralysis, hypoesthesi and rarely quadriparesis can occur in the clinical presentation of the disease. Although MFS is a clinical diagnosis, serological confirmation is possible by identifying the Anti-GQ1b antibody found in most of the affected patients. We prensented an atypical MFS case which is come with swallowing difficulties.
\end{abstract}

Keywords: Ataxia; areflexia; ophthalmoplegia; swallowing. 


\section{GíRiş}

Guillain-Barré sendromu (GBS)'nun bir varyantı olarak kabul edilen Miller-Fisher sendromu (MFS) ataksi, arefleksi ve oftalmopleji kliniği ile karakterizedir. Bununla birlikte hastalığın seyri esnasında pitoz, diplopi, midriyazis, fasial paralizi, hipoestezi, yutma güçlüğü, ses değişikliği gibi klinik bulgular da görülebilir. MFS'li hastaların büyük bir kısmında önceden geçirilmiş bir enfeksiyon öyküsü bulunabilir. Enfeksiyon ajanları içerisinde campylobacter jejuni ve haemaphilus influenza en sık rastalanan patojenlerdir (1). Campylobacter jejuni ve haemaphilus influenza gibi bazı enfeksiyon ajanları periferik sinirlerin yüzeyel ganglizozidlerine benzer bölgeler içerirler. $\mathrm{Bu}$ ajanlara karşı oluşan antikorlar ile sinir dokusu arasında meydana gelen çapraz reaksiyonun klinik bulgulardan sorumlu olduğu düşünülmektedir. Anti-GQ1b, MFS ile ilişkisi en iyi bilinen otoantikordur (2). Anti-GQ1b otoantikoru MFS, GBS ve Bickerstaffs beyinsapı ensefalitinde de yüksek saptanabilir. Serumda Anti-GQ1b otoantikoru \%85-90 olguda klinik bulguların başlamasından sonraki ilk bir hafta içerisinde pozitif saptanmaktadır $(3,4)$. MFS'de albuminositoloijk dissosiasyon müspet olabilir ve elektrofizyoloijk çalışmalarda sensöriyel polinöropati görülebilir $(5,6)$.

\section{OLGU SUNUMU}

Daha önce bilinen herhangi bir yakınması olmayan 73 yaşında erkek hasta acil servisimize iki gün önce başlayan dengesizlik, gıdaları yutamama ve burnundan konuşma şikayeti ile geldi. Özgeçmiş ve soygeçmişinde özellik yoktu. Nörolojik muayenesinde; şuuru açık, oryante, koopere, pupiller izokorik, bilateral ışık refleksleri ve kornea refleksi normal, bilateral göz hareketleri her yöne serbest olarak değerlendirildi. Gag refleksi alınmadı. Göz dibi incelemesi normaldi. Motor defisiti yoktu. Derin tendon refleksleri dört ekstremitede hipoaktif olarak alındı. Bilateral taban cildi refleksi fleksör olarak değerlendirildi. Hastanın ataksik yürüyüşü mevcuttu. Rhomberg testi pozitifti. Tandem walking beceriksiz olarak değerlendirildi. Serebellar testleri bilateral beceriksiz olarak değerlendirildi.

Hemogram ve biyokimya testleri normaldi. Brucella, tiroid fonksiyon testleri, folik asit ve B12 vitamin düzeyi normaldi. Tümör markerları negatif olarak değerlendirildi.

Paraneoplastik sendrom açısından çekilen batın ultrasonografi (USG) normal olarak değerlendirildi.

Hasta servise kabul edildi. Hastada beyin sapı patolojileri veya serebellar patolojiler olabileceği düşünülerek hastanın kranial manyetik rezonans görüntüleme (MR)'si çektirildi. Normal olarak değerlendirildi. Hastaya Myastenia Gravis (MG) olabileceği düşünülerek yorma testi, buz testi ve neostigmin testi yapıldı; yanıt alınamadı. Hastada yatışının 4. gününde bilateral total oftalmopleji gelişti (Şekil I). Derin tendon ref-

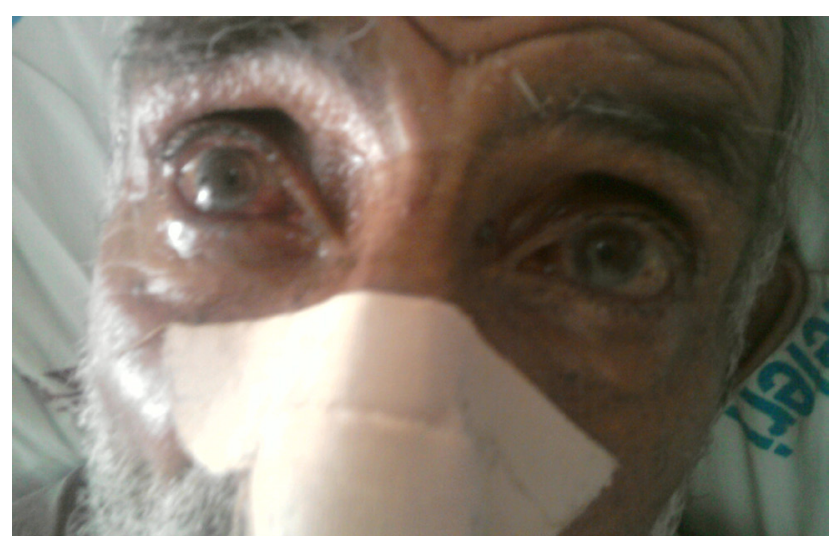

ŞEKIL I: Yatışının 4. gününde total oftalmopleji gelişen hasta.

leksleri dört ekstremitede alınamadı. Hastanın yutma güçlüğü ve burnundan konuşma şikayeti arttı. Hastaya nasogastrik sonda takıldı, total parenteral nutrisyon desteği sağlandı. Hastada MFS düşünüldü. Hastaya elektromiyografi (EMG) yapıldı. Üst ve alt ekstremitelerde duyusal sinir iletileri elde edilmedi. Motor sinir iletileri normal olarak kayıtlandı. Bulgular sensöriyel polinöropati ile uyumlu olarak değerlendirildi. Hastaya yatışının 10. gününde lomber ponksiyon (LP) yapıldı. Beyin-Omurilik sıvısı (BOS) basıncı normal, görünümü berraktı. Glukoz:63mg/ dl (eş zamanlı kan şekeri 104mg/dl) Cl:118m$\mathrm{mol} / \mathrm{L}$. Mikroprotein:65mg/dl olarak geldi. BOS mikroproteini yüksek olarak değerlendirildi. 
Hücre görülmedi. Albuminositolojik dissosiasyon müsbet olarak değerlendirildi. Hastada Anti-GQ1b lgG antikor düzeyi bakıldı. Anti-GQ1b lgG pozitif olarak değerlendirildi. Hastaya 0,4 g/ kg/gün dozunda, 5 gün intravenöz immunglobülin (IVIG) tedavisi verildi. Klinik izlemde yatışının 25. gününde hastanın yutması ve konuşması düzeldi. Nasogastrik sondası çıkarıldı. Sol gözde dışa bakışta minimal kısıtlılık ve ataksi devam ediyordu. Hastanın 3 ay sonra yapılan nörolojik muayenesinde tüm şikayetlerinin düzelmiş olduğu görüldü.

\section{TARTIŞMA}

Akut başlangıçlı dengesizlik, yutma güçlüğü, nazone konuşma şikayeti ile gelen ve bilateral serebellar testleri beceriksiz olarak değerlendirilen hasta da beyin sapı veya serebellar patolojiler olabileceği düşünülmüştü. Hastanın kranial MR'ının normal olması ile bu tanılardan uzaklaşıldı.

Myastenia gravis (MG) asetil kolin reseptörlerine (AchR) karsı oluşan antikorlar nedeniyle nöromüsküler iletideki defektle ortaya çıkan, egzersizle artan kas güçsüzlüğü olarak tanımlanır (7). MG'nin en önemli özelliği yorulmakla artan ve dinlenmekle en azından kısmen düzelen kas güçsüzlüğüdür. Hastalar sabahları düzeldiklerini, belirtilerin akşama doğru ya da yorulunca arttığını ifade ederler. Hastalık çoğu zaman oküler belirtilerle, en sık da pitozla başlar. Buna zamanla çift görme şikayeti de eşlik edebilir. Hastaların çoğunda oküler bulgulara kısa zamanda bulber (orofarengeal) kaslara ve ektremitekaslarına ait belirtilereklenir. Bulber belirtiler konuşma, yutma ve çiğneme güçlüğü, hastalığın en ağır halinde de solunum güçlüğüdür. Okülobulber belirtilerde gün içi fluktuasyonların olması, remisyonların varlığı ve antikolinesterazlara iyi yanıt MG tanısı koymak için yeterli olabilir (8). Ancak tanıyı laboratuvar incelemeleriyle desteklemek önemlidir. Uygun kliniği olan hastalarda MG ile ilişkili antikorların tanımlanması tanının kesinleşmesini sağlar. Jeneralize MG'li hastaların \%85'inde antiasetilkolin reseptör (anti- AChR) antikoru, geri kalanların yarısı kadarında anti-kas spesifik kinaz (anti-MuSK) antikoru bulunur; diğer yarısında ise antikor bulunamaz (seronegatif MG). MG tanısında değerli laboratuvar testleri olan repetitif sinir uyarımı ve tek lif EMG, özellikle seronegatif hastalarda tanı koymakta büyük önem kazanır (9).

Hastamızın yutma güçlüğünün ve halsizlik şikayetinin bulunması üzerine MG olabileceği düşünülerek hastaya provakasyon testleri ve neostigmin testi yapıldı cevap alınmadı. Hastanın repetetif elektromiyografisi (EMG)'si normal olarak değerlendirildi. Hastada MG düşünülmedi.

Botulizm, Clostridium botulinum bakterisinin salgıladığı toksin ile oluşan bir hastalıktır. Toksin motor ve otonomik sinir uçlarından ACh'in salınımını engelleyerek presinaptik bir blokaj yaratır. Genellikle ev konservesi yeme hikayesi vardır. Aynı gıdayı yiyen başkalarında da benzer belirtiler gözlenir. Semptomlar, kontamine gıdanın yenmesinden $12-36$ saat sonra başlar. Bulanık görme, pitozis, midriyazis, ağız kuruluğu, ses kısıklığı, dizartri, yutma güçlüğü ve daha sonra simetrik parezi ve paralizi olabilir. Patolojik refleks ve pupil reaksiyonu alınmaz. Derin tendon refleksleri normal, simetrik olarak azalmış veya alınmayabilir. Duyu kaybı yoktur. BOS incelemesi normaldir (10). Hastamızda ev konservesi yeme hikayesinin olmaması, pupil reaksiyonunun alınması, duyu kaybının olması ve BOS proteinin artması üzerine bu tanıdan uzaklaşıldı.

Miller-Fisher Sendromu, GBS'nin bir varyantı olup klasik triadını ataksi, arefleksi ve oftalmopleji oluşturur. Bulber varyantı yutkunma ve konuşma güçlüğü ile ortaya çıkabilir. Bununla birlikte kol ve bacaklarda hafif güçsüzlük ve uyuşma, kranial sinir tutulumları da görülebilir $(11,12)$. MFS'nin genellikle GBS'den daha iyi bir prognoz gösterdiği düşünülmektedir. MFS tüm GBS olgularının yaklaşık \%5-10 unu oluşturmaktadır (13). Ataksi MFS'de sıklıkla başlangıç semptomlarından biri olup, oldukça ciddi olabilir. MFS'li hastaların çoğunda albuminosito- 
lojik disosiyasyon ilk haftadan sonra belirlenir (14). Serumda anti GQ1b otoantikoru MFS'de hastalığın ilk haftasında, \%85-90 olguda pozitif bulunmaktadır (15). MFS'de serum anti-GQ1b antikorları klinik bulgular ortaya çıktığında en yüksek seviyededir, klinik iyileşme ile paralel olarak 3-4. haftalarda negatif olurlar. Bununla birlikte MFS'li hastaların \%5-10'unda antikorlar hastalığın akut fazında yeterli yüksek seviyede bulunmayabilir $(6,16)$. MFS'nin günümüzde yaygın olarak uygulanan tedavisi IVIG dir. IVIG'e yanıt alınamayan olgularda plazmaferez faydalı olabilir.

Hastamızın ataksi, yutma güçlüğü ve hiponasal konuşma şikayeti ile başvurması, yatışının dördüncü gününde total oftalmoplejisinin gelişmesi ve dört ekstremitede derin tendon reflekslerinin alınamaması, hastanın EMG'sinde üst ve alt ekstremitelerde duyusal sinir iletilerinin elde edilememesi, hastanın yapılan LP'sinde albuminositolojik dissosiasyon müsbet olarak değerlendirilmesi, Anti-GQ1b lgG pozitif olarak değerlendirilmesi, hastanın IVIG tedavisinden fayda görmesi ve 3 ay sonraki nörolojik muayenesinde tüm şikayetlerinin düzelmiş olarak değerlendirilmesinden dolayı hastamızda MFS düşünüldü.

Oldukça nadir görülmesi ve atipik olarak hastanın yutma güçlüğü şikayeti ile gelmesinden dolayı sunulmaya değer bulundu.

\section{KAYNAKLAR}

1. Koga M, Yuki N, Hirata K. Subclass distribution and the secretory component of serum $\lg \mathrm{A}$ antiganglioside antibodies in Guillain-Barré syndrome after Campylobacter jejuni enteritis. J Neuroimmunol 1999;96(2):245-50.

2. Panda S, Tripathi M. Anti-GQ1b antibody syndrome: clinical and immunological range. J Neurol Neurosurg Psychiatry 2002;72(3):418-9.

3. Sladky JT, Ashwal S. Inflammatory neuropathies. In: Swaiman KF, Ashwal S, Ferriero DM, editors. Pediatric neurology. Principles and practice. 4th Edition, Philadelphia: Elsevier, 2006:1923.

4. Bushra JS. Miller-Fisher syndrome: an uncommon acute neuropathy. J Emery Med 2000;18(4):427-30.
5. Lo YL, Chan LL, Pan A, et al. Acute ophthalmoparesis in the anti Q1b antibody syndrome: electrophysiological evidence of neuromusculartransmission defect in the orbicularis oculi. J Neurol Neurosurg Psychiatry 2004;75(3):436-40.

6. Chiba A, KusunokiS, Obata H, Machinami R, Kanazawa I. Serum anti-GQ1b IgG antibody is associated with ophthalmoplegia in Miller Fisher syndrome and Guillan Barre syndrome: clinical and immunohistochemical studies. Neurology 1993;43(10):1911-7.

7. Vincent A, Palace J, Hilto-Jones D. Myasthenia gravis. Lancet 2001;357(9274): 2122-8.

8. Hirch NP. Neuromusculer junction in health and disease. Br J Anaesth 2007;99(1):132-8.

9. Evoli A, Padua L. Diagnosis and therapy of myasthenia gravis with antibodies to muscle-specific kinase. Autoimmun Rev 2013;12(9):931-935.

10. Walter G. Bradley, Robert B. Daroff, Gerald M. Fenichel, C. David Marsden. Neurology in Clinical Practice. 4th Edition, New York: 2000:1338-40.

11. Fisher M. An unusual variant of acute idiopathic polyneuritis (syndrome of ophtalmoplegia, ataxia and areflexia). N Engl J Med 1956;255(2):57-65.

12. Li H, Yuan J. Miller-Fisher syndrome: toward a more comprehensive understanding. Chin Med J. 2001;114(3):235-9.

13. Yuan $C L$, Wang $Y J$, Tsai $C P$. Miller-Fisher syndrome: A hospital-based retrospective study. Eur Neurol 2000;44(2):79-85.

14. Sarnat HB. Guillain Barre Syndrome. In: Kliegman $R M$, Behrman RE, Jenson HB, Stanton BF. Nelson textbook of pediatrics. 18th edition. Philadelphia: WB Saunders 2007;2565-6.

15. Snyder LA, Rismondo V, Miller NR. The Fisher variant of Guillain-Barre syndrome (Fisher syndrome). J Neuroophtalmol 2009;29(4):312-24.

16. Chiba A, Kusunoki S, Shimizu T, Kanazawa I. Serum IgG antibody to gangliozide $G Q 1 b$ is a possible marker of Miller Fisher syndrome. Ann Neurol 1992;31(6):6779. 